\title{
24-month clinical, immuno-virological outcomes and HIV status disclosure in adolescents living with perinatally-acquired HIV in the COHADO cohort, in Togo and Côte d'Ivoire, 2015-2017
}

\section{Marc Harris Dassi Tchoupa Revegue}

INSERM UMR 1027-Universite Toulouse III Paul Sabatier https://orcid.org/0000-0002-1450-5347

\section{Elom Takassi}

Departement of Pediatrics, Centre Hospitalier Universitaire Sylvanus Olympio, Lomé

François Tanoh Eboua

Departement of Pediatrics, Centre Hospitalier Universitaire de Yopougon, Abidjan, Côte d'Ivoire

\section{Sophie Desmonde}

INSERM UMR 1027-Université Toulouse III Paul Sabatier

\section{Ursula Belinda Amoussou-Bouah}

Department of Pediatrics, Centre Hospitalier Universitaire de Yopougon, Abidjan, Côte d'Ivoire

\section{Tchaa Abalo Bakai}

Department of Pediatrics, Centre Hospitalier Universitaire Sylvanus Olympio, Lomé, Togo

\section{Julie Jesson}

INSERM UMR 1027-Universite Toulouse III Paul Sabatier

\section{Désiré Lucien Dahourou}

Département Biomedical et de Santé Publique, Institut de recherche en sciences de la santé (IRSS/CNRST), Ouagadougou, Burkina Faso

\section{Karen Malateste}

INSERM U1219-Epidemiologie-Biostatistique, Université de Bordeaux, Bordeaux, France

Jean-Philippe Raynaud

Service Universitaire de l'enfant et de l'adolescent (SUPEA), CHU de Toulouse, Toulouse, France

\section{Elise Arrivé}

INSERM U1219-Epidémiologie-Biostatistique, Université de Bordeaux, Bordeaux, France

Valériane Leroy ( $\nabla$ valeriane.leroy@inserm.fr)

Inserm U1027, Université Toulouse 3, Toulouse, France https://orcid.org/0000-0003-3542-8616

\section{Research article}

Keywords: Adolescents, HIV, disclosure, retention, West-Africa 
Posted Date: April 14th, 2020

DOI: https://doi.org/10.21203/rs.2.15733/v2

License: (c) (i) This work is licensed under a Creative Commons Attribution 4.0 International License. Read Full License 


\section{Abstract}

Background: Adolescents living with perinatally-acquired HIV (APHIV) face challenges including timely disclosure of their HIV-serostatus that was explored in the West-African COHADO cohort. We assessed the 24-month outcomes in COHADO, among APHIV in relation to the disclosure of their own HIV-serostatus.

Methods: Nested within the International epidemiologic Database to Evaluate AIDS pediatric West African prospective cohort (leDEA pWADA), the COHADO cohort included antiretroviral (ART)-treated APHIV aged 10-19 years, enrolled in HIV-care < 10 years, in Abidjan (Côte d'Ivoire) and Lomé (Togo) in 2015. A favorable 24-month outcome was defined when combining being retained in care, without progression to WHO-AIDS stage, with CD4 cell count > baseline CD4 $( \pm 10 \%)$ and with virological suppression (viral load $[\mathrm{VL}]<50$ copies $/ \mathrm{mL}$ ). We investigated correlates of APHIV favorable 24-month outcome using multivariate logistic regression.

Results: Overall, 209 APHIV were included, 51.6\% in Abidjan, 54.5\% were females. At inclusion, median CD4 cell count was $521 / \mathrm{mm} 3$ (IQR[281-757]); only $29.6 \%$ had a VL measurement of whom $3.2 \%$ in virological suppression. APHIV were younger in Lomé (median age: 12 years (interquartile range [IQR]:1115) compared to Abidjan (14 years (IQR:12-15, $p=0.01$ ). Full HIV-disclosure increased from $41.6 \%$ at inclusion to $74.1 \%$ after 24 months. After 24 months of follow-up, 6 (2.9\%) died, 8 (3.8\%) were lost to follow-up, 4 (1.9\%) were transferred out. Overall, $73.7 \%$ did not progress to WHO-AIDS stage, $62.7 \%$ had CD4 count above $( \pm 10 \%)$ of the baseline value (48.6\% in Abidjan versus $69.0 \%$ in Lomé, $p<0.001)$. Among the $83.7 \%$ with VL measurements, $48.8 \%$ were in virological suppression (Abidjan: $45.4 \%$, Lomé: $52.5 \%, p<0.01)$. The 24 -month combined outcome was favorable for $45 \%$ (29.6\% in Abidjan and $61.4 \%$ in Lomé, $p<0.01$ ). Adjusted on sex, age, a 24-month favorable outcome was not associated with HIVdisclosure status but was significantly higher for APHIV living in Lomé compared to those living Abidjan (adjusted odds ratio $=4.41,95 \% \mathrm{Cl}: 2.29-8.50$ ).

Conclusions: 24-month favorable outcome rates were low among West-African APHIV and differed accross countries. HIV-disclosure frequency improved over time but remained low. Context-specific responses are urgently needed to improve adolescent's care to reach the UNAIDS $90 \%$ target of virological success for those on ART.

\section{Introduction}

Access to antiretroviral therapy (ART) in sub-Saharan Africa has significantly expanded since 2004 [1]. As a result, children living with perinatally-acquired HIV are those HIV-infected though the mother-to-child mode of transmission at any (in utero, during delivery or post-natally through breastfeeding) and are now growing up into adolescence. The critical period of adolescence is characterized by biological, psychosocial changes in a context where HIV disease is turning into a chronic condition $[2,3]$. Globally, 1.8 million adolescents aged 10-19 years were living with HIV in 2017 [4]. Sub-Saharan Africa is the most impacted region, accounting for $84 \%$ of adolescents living with HIV (ALHIV) [4-6]; adolescent girls 
accounted for three-quarters of all new HIV infections among adolescents in 2018 [7]. HIV/AIDS was the leading cause of death amongst adolescents in this region in 2016 [8]. Among the 23 African priority countries, AIDS-related deaths estimated were 24000 [17 000-33 000] from adolescents aged 10-14 years and 25000 [18 000-34 000] among adolescents aged 15-19 years in 2017 [9]. Despite the progress achieved in pediatric HIV care, attention must be paid to the expanding population of adolescents living with either perinatally or non-perinatally acquired HIV, since it is estimated that new HIV infections in adolescents will increase 13\% annually by 2030 in Africa $[10,11]$. This is particularly true in West and Central Africa, which has recorded a 35\% increase in the annual number of AIDS-related deaths among adolescents aged 15-19 years from 2010 to 2016 [12].

Since 2015, universal ART is recommended by WHO [13]. Compared to adults or younger children, adolescent living with perinatally acquired HIV (APHIV) experience higher morbidity, mortality and lower rates of virological suppression on ART $[3,14-16]$. This is most likely related to delayed access to HIV diagnosis and ART in childhood, lack of timely HIV-disclosure while growing-up, with poor medication adherence in a context of prolonged ART, poor retention in care, explained by individual, social, and structural barriers $[6,17-21]$. Transition to adult care also remains a vulnerable step in ALHIV care [22, 23]. All these factors contribute to delaying the UNAIDS' 90-90-90 targets of ALHIV's cascade of care meaning that $90 \%$ of ALHIV living with HIV are knowing their HIV status, $90 \%$ of those infected are on ART and $90 \%$ of those on ART are achieving virological suppression by 2020 [24].

However, timely HIV-disclosure in APHIV is a crucial step to motivate them to adhere to ART and to achieve this 90-90-90 UNAIDS targets [21, 24]. The full-disclosure of an HIV diagnosis includes naming HIV/AIDS, provide information about care and the modes of transmission HIV disease [21]. Unfortunately, a large proportion of APHIV diagnosed during their infancy, remain unaware of their own HIV-positive status while they are growing-up. In many African pediatric sites, even if children or adolescents on ART, healthcare providers and caregivers delayed their HIV-disclosure because of cultural factors, the lack of national guidance [21]. Caregivers are also not ready, and fear their adolescent will disclose the family secret with subsequent stigma [25-28]. According to a previous review, $1.7 \%$ to $41 \%$ of children and ALHIV in low and middle-income countries are fully disclosed of their HIV-positive status [29]. In WestAfrica, less than a third of APHIV knew their status in 2011 and the HIV-disclosure process often occurs late, after the WHO-recommended age of 12 years [30,31]. Data suggested that an earlier full HIVdisclosure could improve ALHIV outcomes through improved ART adherence, retention in care and slower disease progression $[28,32,33]$.

The prospective monitoring of the HIV-disclosure process in APHIV is crucial to understand their clinical, immunological and virological long-term outcomes. To better document outcomes of APHIV in West Africa, the COHADO ("COHort of ADOlescents living with HIV") sub-cohort, as part of the West African International epidemiologic Database to Evaluate AIDS (IeDEA) pediatric cohort Collaboration, was launched in 2015 in two sites of the West-African leDEA pediatric cohort in Lomé (Togo) and Abidjan (Côte d'Ivoire). This study is aimed to better document the HIV-disclosure frequency and its process over 
24 months in relation with 24-month health outcomes among APHIV since inclusion in the COHADO cohort.

\section{Methods}

\section{Study design}

The leDEA pediatric West African Database to evaluate AIDS (pWADA) is an international multicentric prospective cohort as part of the leDEA global pediatric collaboration (https://www.iedea.org/) supported by the US National Institutes of Health since 2006, to describe HIV epidemiology trends and evaluate HIV outcomes using large patient-level observational databases. It included children and adolescent $(<16$ years of age) living with HIV from 11 pediatric clinical centers in seven West African countries (Benin, Burkina Faso, Côte d'Ivoire, Ghana, Mali, Senegal and Togo). It aimed at addressing HIV/AIDS research questions regarding HIV care and outcomes in children and adolescents living with HIV in West Africa [34]. Nested in pWADA, the COHADO prospective cohort was aimed at collecting prospective data to focus on ALHIV specifics issues such as the HIV-disclosure process and behavioral issues in Lomé (Togo) and Abidjan (Côte d'Ivoire) between 2015 and 2017.

\section{Settings and study population}

The COHADO cohort included APHIV from the pediatric pWADA active file of the Teaching Hospital of Yopougon (Abidjan, Côte d'Ivoire) and the Sylvanus Olympio Teaching Hospital (Lomé, Togo). In accordance with national guidelines, APHIV followed up in these sites were typically seen in medical consultation quarterly. CD4 count were measured six-monthly, and since 2016, viral load was monitored on a yearly basis.

Between January 2015 and November 2015, ART-treated ALHIV aged 10-19 years, included in HIV-care before the age of 10 years (as a proxy of perinatal infection in the absence of know mode of transmission), and followed up in the two participating sites, were invited to participate in the study.

\section{Data collection}

Study-specific data including living and schooling condition, parents' vital status, access to running water, access to electricity, disclosure (at baseline and during follow-up) and disclosure process, were recorded using standardized questionnaires assessed yearly. Other sociodemographic, clinical and therapeutic data were extracted from medical records and from the leDEA pediatric central database.

HIV-disclosure process data (disclosure status, date of full disclosure, person in charge of disclosure) were recorded from parents/legal guardian to avoid any accidental HIV-disclosure to the adolescent 
during the interview. HIV-disclosure was defined as full disclosure when the APHIV has been told that he or she has HIV/AIDS specifically, and he/she knew the care and the modes of transmission [21].

Treatment adherence was evaluated by the counsellor, using the ratio between the number of pills prescribed and the number of pills taken during the four days preceding the visit. Good treatment adherence was defined as more than $95 \%$ of planned doses taken.

\section{Data analysis}

Baseline was defined as the date of inclusion in the COHADO cohort. Our endpoint, a 24-month favorable outcome, was measured at the 24-month visit combining multiple criteria: (i) vital status (alive, died, lost to follow-up); (ii) clinical criteria (WHO clinical stage [35] evolution from baseline); (iii) immunological criteria (difference in CD 4 count since baseline); (iv) virological criteria (HIV viral load). APHIV was defined as lost to follow-up if s/he did not report for any follow-up for at least 6 months, and for whom transfer, or vital status was unknown.

After describing each criterion separately, we assessed a combined outcome pooling all criteria at 24 months. A favorable combined outcome was defined as being alive and followed up without progression to WHO AIDS stage; having a CD 4 cell count above the baseline value $( \pm 10 \%)$ and being in virological suppression (viral load $<50$ copies $/ \mathrm{mL}$ ). APHIV with missing data in one of the evaluation criterion were classified using the other criterion and we performed sensitivity analyses.

We described APHIV baseline characteristics using median values with inter-quartile ranges (IQR) for continuous variables and proportions for categorized variable, globally and by site. Full HIV-disclosure was assessed over the 24 months of follow-up: APHIV were classified as non-disclosed, disclosed to during the past 2 years (after inclusion in COHADO), and disclosed to $>2$ years, thus before inclusion in COHADO (for them, the timing of disclosure was often not recorded).

We described 24-month outcomes overall, according to site, disclosure status and other baseline characteristics. Correlates of favorable combined outcome in COHADO at 24 months of follow-up were investigated using a backward stepwise logistic regression analysis, including all co-variables significantly associated at a $20 \%$ threshold in the univariate analyses. Age and sex were forced in the final multivariate model. We tested for country-specific practices adding an interaction between disclosure and country, but this was non-significant. All analyses were performed using STATA 14.2 (Statacorp, College Station, TX, USA).

\section{Results}

\section{Selection and inclusion of ALHIV in the COHADO cohort}


From January 2015 to November 2015, 511 ALHIV visited the sites of Abidjan and Lomé. Among them, a total of 209 (40.9\%) APHIV were offered enrolment in COHADO and gave their consent (Figure 1).

Reasons for not being included were mainly due to either refusal of parents and APHIV, or the low availability of health care workers to propose participating in the study, due to over workload. ALHIV included in COHADO did not differ from others who visited the sites in terms of sex, age and immunological status distributions at baseline. However, there were high rates of missing data for both WHO clinical staging and viral load data (Table 1).

\section{Baseline characteristics}

Baseline characteristics are presented in Table 2. Among the 209 APHIV included, $51.7 \%(n=108)$ lived in Abidjan and $54.6 \%(n=114)$ were female. Median age was 13 [IQR: 11-15] years; APHIV were significantly older in Abidjan compared to Lomé $(p=0.01)$. The APHIV median ART duration prior to inclusion in COHADO was 6 [IQR: 4-10] years and it was significantly longer in Abidjan than in Lomé $(p<0.01)$.

Only $23.9 \%$ of the cohort lived with both biological parents. Most APHIV (89.9\%) were from urban areas, $97.1 \%$ had access to electricity and $62.7 \%$ had access to piped drinking water at home.

Overall, $17.2 \%$ had already reached the WHO AIDS stage 4 at baseline, this proportion was higher in Lomé $(32.7 \%)$ compared to Abidjan (2.8\%) $(\mathrm{p}<0.01)$. Regarding ART, 81.2\% were on an NNRTI-based regimen, and $56.4 \%$ of APHIV were good adherent to ART, as defined in the methods section. Only $29.6 \%$ of APHIV had a viral load measurement, of whom $3.2 \%$ reached virological suppression $(<50 \mathrm{cp} / \mathrm{mL})$.

At baseline, $41.6 \%$ were already fully disclosed of their HIV-serostatus, this proportion was significantly higher in Abidjan (57.4\%) compared to Lomé $(24.8 \%, p<0.01)$.

\section{4-month outcomes}

Among the 209 APHIV, 32.5\% were HIV-disclosed over the 24-month follow-up period, reaching a proportion of $74.1 \%$ who were fully HIV-disclosed at endpoint (+78.1\% compared to baseline, $p<0.01$ ). During follow-up, the increase in HIV disclosure frequency relatively to baseline was stronger in Lomé $(+52.5 \%)$ than in Abidjan $(+13.9 \%)(p<0.01)$. (Table 3$)$

By 24 months, six APHIV had died (2.9\%) and eight were lost to follow-up (3.8\%). Among the 209 APHIV, the 24-month combined outcome was favorable for $45 \%$ of APHIV. The proportion of APHIV with a favorable outcome was higher in Lomé $(61.4 \%)$ compared to Abidjan $(29.6 \%, p<0.01)$ (Table 3$)$.

\section{HIV disclosure process characteristics}


The APHIV informed of their own HIV-serostatus at the endpoint were significantly older (median age: 16 [IQR: 14-18] years) than those not informed (median age: 13 years [IQR: 12-14]) $(p<0.01)$. These APHIV also tended to be more advanced in HIV disease and had significantly lower median CD 4 cell $(22.6 \%$ at WHO stage 4/AIDS; CD4 cell count: 508 cells/ $\mathrm{mm}^{3}$ [IQR: 348-750]) compared to those not disclosed to (14.8\% at WHO stage 4/AIDS; CD4 cell count: 596 cells/mm³ [IQR: 455-871]) (Table 4).

Questioned about the reason of non-disclosure at baseline, parents/legal guardians of the 122 APHIV unaware of their HIV-serostatus declared fear of the adolescent's reaction (75.0\%) and fear of HIV status divulgation to others $(69.1 \%)$ as the most frequent reasons. Other reasons included the young age of APHIV (52.9\%) and the fact that parents were also not prepared (35.3\%).

Among the 155 APHIV who were fully HIV-disclosed to by last contact, both parents (40.7\%) and psychologists (54.2\%) were the most involved in the HIV disclosure process; at the contrary, doctors have very little involvement in the process, only $5.2 \%$ of APHIV (Table 5).

\section{Factors associated with a favorable 24-month combined outcome}

Table 6 presents the correlates of a 24-month favorable combined outcome in APHIV. In the univariate analysis, we found that APHIV from Lomé (vs Abidjan), without access to piper water (vs with access to piper water) and with baseline WHO clinical stage 4 (vs WHO clinical stage 1,2,3) were significantly more likely to have a 24-month favorable outcome. Contrariwise, being an orphan tended to reduce the odds of a 24-month favorable outcome, but this was not significant.

In the final model, adjusted for sex, age and disclosure status, APHIV disclosure status was not associated with having a favorable 24-month outcome (Disclosed $\leq 2$ years since baseline: adjusted odds ratio $(\mathrm{aOR})=0.50,95 \% \mathrm{Cl}[0.21-1.15], \mathrm{p}=0.10$; Disclosed $>2$ years since baseline: $(\mathrm{aOR})=0.65,95 \% \mathrm{Cl}$ [0.25-1.72], $p=0.39$ ) (Table 6). APHIV from Lomé were four times more likely to have a favorable 24month outcome compared to those from Abidjan (aOR: 4.41, 95\% Cl [2.29-8.50]).

We performed sensitivity analyses for APHIV with 24-month outcomes defined with one missing criterion, the result remained similar, with no significant effect of disclosure.

\section{Discussion}

For the first time to our knowledge, this cohort reports a snapshot on the clinical, immunological and virological outcomes of APHIV measured over 24-month in relation to HIV-disclosure in two West African pilot sites contributing to the leDEA West Africa collaboration. We made several key findings: first, the COHADO project has encouraged the full HIV-serostatus disclosure to APHIV, with an increase from $46.1 \%$ to $74.1 \%$ after 24 months, but we still found that one in four APHIV remained not formally disclosed of his/her own HIV-serostatus at the endpoint while they all were aged above 13 years. Second, unlike the 
caregivers and the psychologists, doctors have very little involvement in the disclosure process. Third, we found that those APHIV disclosed to were at a more advanced stage of the disease than those unaware of their status. Fourth, after 24-month of follow-up, the cumulative death rate was high, close to $3 \%$, and only $45 \%$ of APHIV had a favorable 24 month combined outcome after two years of follow-up. Finally, adjusted on sex, age, the HIV disclosure status was not associated with the outcome, but strongly with the site context: APHIV from Lomé increased by four the odds of a favorable 24-month outcome compared to those from Abidjan.

Although the frequency of ALHIV fully disclosed of their HIV-serostatus varies according to studies in Africa, it remains overall low ranging from $16 \%$ to $39 \%$ [36-41]. In our study, we found that only $46.1 \%$ knew their HIV status at baseline, and $74.1 \%$ by 24 months of follow-up. Although this should be closer to $100 \%$ according to the WHO recommendations, this is higher than reported in previous studies, particularly for West Africa [25, 31, 42]. In Ghana, two separate studies reported the proportion of HIV disclosure to be $11.2 \%$ among children and adolescents aged 8-14 years in 2009 and $44 \%$ among ALHIV aged 12 -19 years in 2015 [25, 43]. Furthermore, we observed an increase in the HIV-disclosure process over the 24-month follow-up period. This is clearly visible in Lome where the proportion of APHIV disclosed had increased from $24.8 \%$ to $77.2 \%$. One of our hypothesis is that likely occurred after a 3-day training workshop on HIV-serostatus disclosure to ALHIV delivered in 2016, in Abidjan and involving the HIV health professionals from all the leDEA-pWADA sites [44]. This workshop may have changed the heath care workers' practices regarding disclosure and explain the significant increase of HIV-disclosure rate at the endpoint, but we also acknowledge that this is can be only correlated to the adolescent age.

As a matter of fact, we found that few doctors are involved in the process of HIV-disclosure, and they tended to delegate the disclosure practice to others for several reasons including over clinical work load, or fear in doing it. Indeed, healthcare workers face structural issues including limited human and technical resources, whereas disclosure is a complex process which needs time and training [21, 28]. In 2018, there were too few counselors working in the current HIV-programs. Thus, when existing in the HIVprograms, psychologists are better trained to address mental issues such as HIV-related stigma and taboo, explaining their good in the process. But they became the only person being in charge in the full HIV-disclosure process and they are not always daily available. Therefore, we feel that the whole staff should be involved in the HIV-disclosure with a multidisciplinary approach and task-sharing. That approach should be set-up at each HIV program level to offer a comprehensive care, including the process of HIV status disclosure. It is important for national and regional programmes, to tailor locally appropriate strategies to improve disclosure practice, such as the training of multidisciplinary team on disclosure mentioned earlier [34]. Furthermore, caregivers are also unprepared for disclosure and fear ALHIV stigmatization. For many parents, children are too young or are not ready to receive HIV-disclosure $[26,29,45]$. The role and benefits of having caregivers involved in the HIV disclosure process remain unclear. While some studies have suggested that caregivers are in a much better position to disclose ALHIV serostatus, others have reported that according to ALHIV, health workers are better placed [46-48]. 
Nevertheless, a better understanding of what refrain caregivers to disclose their HIV-status to their child is important to support them accordingly.

We found that APHIV disclosed of their HIV status tended to have worse immunological and clinical condition than those not disclosed. Unfortunately, we were not able to assess the exact timing of HIV disclosure as this is an evolving process that can take several clinical visits. We make however, two main hypotheses that could explain this observation. Either HIV disclosure had a negative effect on the APHIV leading to poor ART adherence and thus poor clinical outcomes. Or, it is the poor immunological and clinical condition of the patient that led to HIV-disclosure, in order to improve urgently their health condition via the improvement of their adherence to ART. We feel, in the context of our study, that this second hypothesis is most likely. This indication bias could have reduced the disclosure effect measured at the $24^{\text {th }}$ month, since APHIV disclosed have worse health conditions. We also noted that those disclosed to were significantly older, and therefore most likely to be at a more advanced stage of the disease. Previous cohort studies, in both high and low income settings have reported that younger age of APHIV is associated with less frequent WHO 4 clinical stage compared to older APHIV $[49,50]$.

During follow-up, the cumulative death rate reached $3 \%$. While this seems high, it is lower than that reported in other studies conducted in ALHIV in sub-Saharan Africa, where it ranged from 4-6\% [33, 51]. Although these rates remain in the same order of magnitude, our lower rate could be explained by the shorter follow-up duration.

Overall, $45 \%$ of APHIV had favorable combined 24-month outcome; this was more frequent in Lomé than in Abidjan. However, APHIV in Lomé were in poorer clinical and immunological condition compared to those from Abidjan, and therefore had more leeway to reach a favorable 24-month outcome. Although, we were not able to document different sub-types, we do not support a difference between the two sites to explain the difference. Our finding highlights rather differences of care practices and resources available between West African cities, which must be considered to improve APHIV care. Nevertheless, our outcomes are observed in the context where about $80 \%$ of APHIV were receiving a NNRTI-therapy with a limited access to second-line therapy, common in West-Africa. The sub-optimal virological response in our population is in line with the results reported in a snapshot-study conducted in Lomé in 2016, with high rates of virological failure and drug resistance [16].

Many studies have reported on how HIV disclosure improves ALHIV clinical, immunological and virological outcomes as well as retention in care[28, 32, 33, 51, 52]. In COHADO, we found that HIV disclosure tend to reduce the odds of having a favorable 24-month outcome, though this was not significant. This result could partially be explained by the disclosure indication bias induced in COHADO, previously mentioned, where disclosure is prompted by the advanced stage of the disease. We advise caution in the interpretation of this observation. Because the disclosure variable was not standardized, nor we did not have the date of disclosure for all APHIV. A substantial proportion of APHIV was indeed disclosed before inclusion in COHADO cohort and without disclosure date. So, the association between 
disclosure and the 24-month favorable outcome is evaluated at a time too soon for some APHIV and too far for others.

It has been previously reported that ALHIV non-disclosure of HIV-serostatus increases virological failure by a 5 -fold [53]. The identification of virological failure is possible where viral load measurement is available, which was not routinely done in West Africa. The COHADO cohort is one of the first study to provide viral load data in West-Africa, with measurements more available at the $24^{\text {th }}$ month of follow-up. Viral load access is a real issue in ALHIV care monitoring in Africa, and the prioritization of viral load measurement is universally recommended since 2016 particularly among ALHIV who have high risk of virological failure[53]. In the COHADO clinical sites, the annual viral load measurement is a recent opportunity that should be scaled up and supported in every HIV-care facility, as virological success could be also used to optimize treatment adherence and outcomes of APHIV.

Our study met several limitations. First, we enrolled less than half of APHIV who visited the sites during the inclusion period due to logistical issues, mainly related to health care workers overwork with little time to propose the study and get formally the parent's consent. Although those included did not differ significantly from those not included, the small sample size may have limited the statistical power of our analysis. Second, we selected our APHIV in urban referral center for adolescent HIV care where APHIV are likely receiving better standard of care compared to the general population in these cities. Third, the few time points in the follow-up did not allow us to perform a longitudinal analysis. However, the COHADO cohort reported a small proportion of lost to follow-up reflecting high quality of follow-up in the selected sites. Nevertheless, our study provides original data documenting the feasibility and indirectly the positive effect of accompanying actively the HIV disclosure process using health care worker training on this topic, and routine monitoring of this crucial event. Second, to our knowledge, this study gives a representative and longitudinal assessment of the virological response in APHIV on lifelong ART that could be further used as a reference.

\section{Conclusions}

The COHADO cohort study assessed the HIV-disclosure process and outcomes of APHIV in two West African urban clinical sites. Although the frequency of full HIV disclosure remains low, this project encouraged full HIV-disclosure serostatus to APHIV with documented results. The 24-month outcome of APHIV was favorable for slightly less than half of them and differ according to sites.

Urgent interventions are needed to support timely APHIV disclosure practices in both caregivers and health care workers. These interventions to improve full HIV-disclosure to APHIV, may consider disclosure as a dynamic process that should be monitored over time and include caregivers, and healthcare providers. It is also urgent to reduce morbidity and mortality in ALHIV in West Africa. The country effect on the favorable outcomes of ALHIV suggested the need for a better distribution of health workers and resources, the need for context-specific interventions. Finally, it is crucial to monitor closely virological outcomes of ALHIV on lifelong ART. This study provides a reference to tailor context-specific interventions 
in West-Africa. Cohort studies among ALHIV such as in pWADA may offer unique opportunity to optimize monitoring and standardized data collection and offer interventional packages to address specifics ALHIV issues including disclosure, ART adherence, virological outcome, drug resistance mental and sexual health with the perspective of improving the 90-90-90 cascade in ALHIV population.

\section{Abbreviations}

AIDS Acquired immune deficiency syndrome

ALHIV Adolescents living with HIV

APHIV Adolescents living with perinatally-acquired HIV

ART Antiretroviral therapy

HIV Human immune deficiency virus

leDEA International epidemiologic Database to Evaluate AIDS

IQR Inter-quartile range

MD Medical Doctor

NNRTI Non-nucleoside reverse transcriptase inhibitors

pWADA pediatric West African Database on AIDS

WHO World Health Organization

\section{Declarations}

\section{Ethics approval and consent to participate}

This study received authorizations of the health ministries and national ethics committee of Togo and Côte d'Ivoire. All the participants and their caregivers gave their oral and written informed consent to participate.

\section{Consent for publication}

Not applicable

\section{Availability of data and materials}


The datasets generated and/or analysed during the current study are not publicly available but are available from the corresponding author on reasonable request.

\section{Competing interests}

The authors declare that they have no competing interests

\section{Funding}

Research reported in this publication was supported by the US National Institutes of Health (NIAID, NICHD, $\mathrm{NCl}$ and NIMH) under Award Number U01Al069919 (PI: Dabis). The content is solely the responsibility of the authors and does not necessarily represent the official views of the National Institutes of Health. J.J. and S.D. were funded by Sidaction.

\section{Authors' contributions}

MHDTR. conducted the analyses, wrote the first draft of paper under V.L. supervision.

SD, JJ, DD, KM, EA, JPR and VL reviewed and edited the paper. KM and VL were involved in the database management, the study design, and the statistical analyses. VL was involved in the pediatric leDEA cohort coordination and fund raising. ET, FTE, BB, FB, were in charge of the cohort of adolescents and the database recording in each country involved in the study. All authors have read and approved the final manuscript.

\section{Acknowledgments}

The authors thank all the participating children and their families, as well as all the members of the hospital teams of the sites involved in the leDEA West Africa pediatric cohort.

Research reported in this publication was supported by the US National Institutes of Health (NIAID, NICHD, $\mathrm{NCl}$ and NIMH) under Award Number U01Al069919 (PI: Dabis).

The leDEA West African Collaboration: Site investigators and cohorts: Adult cohorts: Marcel Djimon Zannou, CNHU, Cotonou, Benin; Armel Poda, CHU Souro Sanou, Bobo Dioulasso, Burkina Faso; Fred Stephen Sarfo \& Komfo Anokeye Teaching Hospital, Kumasi, Ghana; Eugene Messou, ACONDA CePReF, Abidjan, Côte d'Ivoire; Henri Chenal, CIRBA, Abidjan, Côte d'Ivoire; Kla Albert Minga, CNTS, Abidjan, Côte d'Ivoire; Emmanuel Bissagnene \& Aristophane Tanon, CHU Treichville, Côte d'Ivoire; Moussa Seydi, CHU 
de Fann, Dakar, Senegal; Akessiwe Akouda Patassi, CHU Sylvanus Olympio, Lomé, Togo. Pediatric cohorts: Sikiratou Adouni Koumakpai-Adeothy, CNHU, Cotonou, Benin; Lorna Awo Renner, Korle Bu Hospital, Accra, Ghana; Sylvie Marie N'Gbeche, ACONDA CePReF, Abidjan, Ivory Coast; Clarisse Amani Bosse, ACONDA_MTCT+, Abidjan, Ivory Coast; Kouadio Kouakou, CIRBA, Abidjan, Côte d'Ivoire; Madeleine Amorissani Folquet, CHU de Cocody, Abidjan, Côte d'Ivoire; François Tanoh Eboua, CHU de Yopougon, Abidjan, Côte d'Ivoire; Fatoumata Dicko Traore, Hopital Gabriel Toure, Bamako, Mali; Elom Takassi, CHU Sylvanus Olympio, Lomé,Togo. Coordinating \& data centers: ADERA, ISPED \& INSERM U1219, Bordeaux, France : François Dabis, Renaud Becquet, Charlotte Bernard, Shino Chassagne Arikawa, Antoine Jaquet, Karen Malateste, Elodie Rabourdin, Thierry Tiendrebeogo. INSERM U1027, Toulouse, France: Désiré Dahourou, Sophie Desmonde, Julie Jesson, Valeriane Leroy. PACCl, CHU Treichville, Abidjan, Côte d'Ivoire: Didier Koumavi Ekouevi, Jean-Claude Azani, Patrick Coffie, Abdoulaye Cissé, Guy Gnepa, Apollinaire Horo, Christian Kouadio, Boris Tchounga.

\section{References}

1. WHO | Scaling up priority HIV/AIDS interventions in the health sector. WHO. https://www.who.int/hiv/pub/2010progressreport/report/en/. Accessed 13 May 2019.

2. Patel K, Hernán MA, Williams PL, Seeger JD, Mclntosh K, Van Dyke RB, et al. Long-term effectiveness of highly active antiretroviral therapy on the survival of children and adolescents with HIV infection: a 10-year follow-up study. Clin Infect Dis Off Publ Infect Dis Soc Am. 2008;46:507-15.

3. Lowenthal ED, Bakeera-Kitaka S, Marukutira T, Chapman J, Goldrath K, Ferrand RA. Perinatally acquired HIV infection in adolescents from sub-Saharan Africa: a review of emerging challenges. Lancet Infect Dis. 2014;14:627-39.

4. Children and AIDS: Statistical Update. UNICEF DATA. 2017. //data.unicef.org/resources/childrenaids-statistical-update/. Accessed 28 Mar 2018.

5. AIDSinfo | UNAIDS. http://aidsinfo.unaids.org/. Accessed 26 Feb 2018.

6. Slogrove AL, Sohn AH. The global epidemiology of adolescents living with HIV: time for more granular data to improve adolescent health outcomes. Curr Opin HIV AIDS. 2018;13:170-8.

7. Adolescent HIV prevention. UNICEF DATA. https://data.unicef.org/topic/hivaids/adolescents-youngpeople/. Accessed 23 Oct 2018.

8. Lim SS, Allen K, Bhutta ZA, Dandona L, Forouzanfar MH, Fullman N, et al. Measuring the healthrelated Sustainable Development Goals in 188 countries: a baseline analysis from the Global Burden of Disease Study 2015. The Lancet. 2016;388:1813-50.

9. UNAIDS. Start free, stay free, AIDS free: 2017 progress report. UNAIDS Geneva, Switzerland; 2017.

10. For Every Child, End AIDS: Seventh Stocktaking Report, 2016. UNICEF DATA. 2016. http//data.unicef.org/resources/every-child-end-aids-seventh-stocktaking-report-2016/. Accessed 6 Mar 2017. 
11. Global AIDS Response Progress Reporting 2016. UNAIDS. (2016).

http://www.aidsdatahub.org/global-aids-response-progress-reporting-2016-unaids-2016. Accessed 12 Sep 2017.

12. Step Up the Pace: Towards an AIDS-free generation in West and Central Africa. UNICEF. https://www.unicef.org/publications/index_101480.html. Accessed 11 Oct 2018.

13. WHO | Consolidated guidelines on the use of antiretroviral drugs for treating and preventing HIV infection. WHO. http://www.who.int/hiv/pub/arv/arv-2016/en/. Accessed 1 Feb 2017.

14. Judd A, Lodwick R, Noguera-Julian A, Gibb DM, Butler K, Costagliola D, et al. Higher rates of tripleclass virological failure in perinatally HIV-infected teenagers compared with heterosexually infected young adults in Europe. HIV Med. 2017;18:171-80.

15. Nachega JB, Hislop M, Nguyen H, Dowdy DW, Chaisson RE, Regensberg L, et al. Antiretroviral therapy adherence, virologic and immunologic outcomes in adolescents compared with adults in southern Africa. J Acquir Immune Defic Syndr 1999. 2009;51:65-71.

16. Salou M, Dagnra AY, Butel C, Vidal N, Serrano L, Takassi E, et al. High rates of virological failure and drug resistance in perinatally HIV-1-infected children and adolescents receiving lifelong antiretroviral therapy in routine clinics in Togo. J Int AIDS Soc. 2016;19. doi:10.7448/IAS.19.1.20683.

17. Sohn AH, Hazra R. Old Problems for New Providers: Managing the Postpediatric HIV Generation. Clin Infect Dis Off Publ Infect Dis Soc Am. 2017;64:1113-4.

18. CIPHER Global Cohort Collaboration. Inequality in outcomes for adolescents living with perinatally acquired HIV in sub-Saharan Africa: a Collaborative Initiative for Paediatric HIV Education and Research (CIPHER) Cohort Collaboration analysis. J Int AIDS Soc. 2018;21:n/a-n/a.

19. Hudelson C, Cluver L. Factors associated with adherence to antiretroviral therapy among adolescents living with HIV/AIDS in low- and middle-income countries: a systematic review. AIDS Care. 2015;27:805-16.

20. Lamb MR, Fayorsey R, Nuwagaba-Biribonwoha H, Viola V, Mutabazi V, Alwar T, et al. High attrition before and after ART initiation among youth (15-24 years of age) enrolled in HIV care. AIDS Lond Engl. 2014;28:559-68.

21. Dahourou D, Raynaud J-P, Leroy V. The challenges of timely and safe HIV disclosure among perinatally HIV-infected adolescents in sub-Saharan Africa: Curr Opin HIV AIDS. 2018;:1.

22. Straub DM, Tanner AE. Health-care transition from adolescent to adult services for young people with HIV. Lancet Child Adolesc Health. 2018;2:214-22.

23. Dahourou DL, Gautier-Lafaye C, Teasdale CA, Renner L, Yotebieng M, Desmonde S, et al. Transition from paediatric to adult care of adolescents living with HIV in sub-Saharan Africa: challenges, youthfriendly models, and outcomes. J Int AIDS Soc. 2017;20. doi:10.7448/ias.20.4.21528.

24. HIV/AIDS (UNAIDS) JUNP on. 90-90-90-an ambitious treatment target to help end the AIDS epidemic. Geneva: UNAIDS; 2014. 2017.

25. Gyamfi E, Okyere P, Enoch A, Appiah-Brempong E. Prevalence of, and barriers to the disclosure of HIV status to infected children and adolescents in a district of Ghana. BMC Int Health Hum Rights. 
2017;17:8.

26. Brown BJ, Oladokun RE, Osinusi K, Ochigbo S, Adewole IF, Kanki P. Disclosure of HIV status to infected children in a Nigerian HIV Care Programme. AIDS Care. 2011;23:1053-8.

27. Wright S, Amzel A, Ikoro N, Srivastava M, Leclerc-Madlala S, Bowsky S, et al. Talking to children about their HIV status: a review of available resources, tools, and models for improving and promoting pediatric disclosure. AIDS Care. 2017;29:1019-25.

28. Vreeman RC, Gramelspacher AM, Gisore PO, Scanlon ML, Nyandiko WM. Disclosure of HIV status to children in resource-limited settings: a systematic review. J Int AIDS Soc. 2013;16. doi:10.7448/IAS.16.1.18466.

29. Britto C, Mehta K, Thomas R, Shet A. Prevalence and Correlates of HIV Disclosure Among Children and Adolescents in Low- and Middle-Income Countries: A Systematic Review. J Dev Behav Pediatr JDBP. 2016;37:496-505.

30. WHO | Guideline on HIV disclosure counselling for children up to 12 years of age. WHO. http://www.who.int/hiv/pub/hiv_disclosure/en/. Accessed 24 Jan 2018.

31. Meless GD, Aka-Dago-Akribi H, Cacou C, François Eboua T, Edmond Aka A, Maxime Oga A, et al. Notification of HIV status disclosure and its related factors in HIV-infected adolescents in 2009 in the Aconda program (CePReF, CHU Yopougon) in Abidjan, Côte d'Ivoire, The PRADO-Cl Study. J Int AIDS Soc. 2013;16. doi:10.7448/IAS.16.1.18569.

32. Odiachi A. The Impact of Disclosure on Health and Related Outcomes in Human Immunodeficiency Virus-Infected Children: A Literature Review. Front Public Health. 2017;5:231.

33. Arrivé E, Dicko F, Amghar H, Aka AE, Dior H, Bouah B, et al. HIV Status Disclosure and Retention in Care in HIV-Infected Adolescents on Antiretroviral Therapy (ART) in West Africa. PLOS ONE. 2012;7:e33690.

34. Ekouevi DK, Azondekon A, Dicko F, Malateste K, Touré P, Eboua FT, et al. 12-month mortality and lossto-program in antiretroviral-treated children: The leDEA pediatric West African Database to evaluate AIDS (pWADA), 2000-2008. BMC Public Health. 2011;11:519.

35. World Health Organization. WHO case definitions of HIV for surveillance and revised clinical staging and immunological classification of HIV-related disease in adults and children. Geneva: Geneva: World Health Organization; 2007. http://apps.who.int/iris/handle/10665/43699. Accessed 14 Jan 2019.

36. Bikaako-Kajura W, Luyirika E, Purcell DW, Downing J, Kaharuza F, Mermin J, et al. Disclosure of HIV status and adherence to daily drug regimens among HIV-infected children in Uganda. AIDS Behav. 2006;10 4 Suppl:S85-93.

37. Menon A, Glazebrook C, Campain N, Ngoma M. Mental Health and Disclosure of HIV Status in Zambian Adolescents With HIV Infection: Implications for Peer-Support Programs. JAIDS J Acquir Immune Defic Syndr. 2007;46:349-54.

38. Atwiine B, Kiwanuka J, Musinguzi N, Atwine D, Haberer JE. Understanding the role of age in HIV disclosure rates and patterns for HIV-infected children in southwestern Uganda. AIDS Care. 
2015;27:424-30.

39. Abebe W, Teferra S. Disclosure of diagnosis by parents and caregivers to children infected with HIV: Prevalence associated factors and perceived barriers in Addis Ababa, Ethiopia. AIDS Care. 2012;24:1097-102.

40. Nzota MS, Matovu JKB, Draper HR, Kisa R, Kiwanuka SN. Determinants and processes of HIV status disclosure to HIV - infected children aged 4 to 17 years receiving HIV care services at Baylor College of Medicine Children's Foundation Tanzania, Centre of Excellence (COE) in Mbeya: a cross-sectional study. BMC Pediatr. 2015;15. doi:10.1186/s12887-015-0399-3.

41. Negese D, Addis K, Awoke A, Birhanu Z, Muluye D, Yifru S, et al. HIV-Positive Status Disclosure and Associated Factors among Children in North Gondar, Northwest Ethiopia. ISRN AIDS. 2012;2012. doi:10.5402/2012/485720.

42. Gyamfi E, Okyere P, Appiah-Brempong E, Adjei RO, Mensah KA. Benefits of Disclosure of HIV Status to Infected Children and Adolescents: Perceptions of Caregivers and Health Care Providers. J Assoc Nurses AIDS Care. 2015;26:770-80.

43. Kallem S, Renner L, Ghebremichael M, Paintsil E. Prevalence and pattern of disclosure of HIV status in HIV-infected children in Ghana. AIDS Behav. 2011;15:1121.

44. Dahourou D, David M, Aka-Dago-Akribi H, Gautier-Lafaye C, Cacou C, Raynaud J-P, et al. Annonce à l'enfant et à l'adolescent de son statut VIH en Afrique francophone centrale et de l'Ouest. Bull Société Pathol Exot. 2019; In press.

45. Aderomilehin O, Hanciles-Amu A, Ozoya OO. Perspectives and Practice of HIV Disclosure to Children and Adolescents by Health-Care Providers and Caregivers in sub-Saharan Africa: A Systematic Review. Front Public Health. 2016;4:166.

46. Beima-Sofie K, John-Stewart G, Shah B, Wamalwa D, Maleche-Obimbo E, Kelley M. Using health provider insights to inform pediatric HIV disclosure: a qualitative study and practice framework from Kenya. AIDS Patient Care STDs. 2014;28:555-64.

47. Moodley K, Myer L, Michaels D, Cotton M. Paediatric HIV disclosure in South Africa -- caregivers' perspectives on discussing HIV with infected children. South Afr Med J Suid-Afr Tydskr Vir Geneeskd. 2006;96:201-4.

48. Kidia KK, Mupambireyi Z, Cluver L, Ndhlovu CE, Borok M, Ferrand RA. HIV status disclosure to perinatally-infected adolescents in Zimbabwe: a qualitative study of adolescent and healthcare worker perspectives. PloS One. 2014;9:e87322.

49. Neilan AM, Karalius B, Patel K, Van Dyke RB, Abzug MJ, Agwu AL, et al. Association of Risk of Viremia, Immunosuppression, Serious Clinical Events, and Mortality With Increasing Age in Perinatally Human Immunodeficiency Virus-Infected Youth. JAMA Pediatr. 2017;171:450-60.

50. Desmonde S, Neilan AM, Malateste K, Yiannoutsos C, Musick B, Patten GB. Age-stratified rates of mortality and key clinical events in youth ages 0-24 years in the multiregional leDEA network. In: 9th International HIV Pediatrics Workshop. 2017. 
51. Ngeno B, Waruru A, Inwani I, Nganga L, Wangari EN, Katana A, et al. Disclosure and Clinical Outcomes Among Young Adolescents Living With HIV in Kenya. J Adolesc Health. 2019;64:242-9.

52. Montalto GJ, Sawe FK, Miruka A, Maswai J, Kiptoo I, Aoko A, et al. Diagnosis disclosure to adolescents living with HIV in rural Kenya improves antiretroviral therapy adherence and immunologic outcomes: A retrospective cohort study. PLoS ONE. 2017;12. doi:10.1371/journal.pone.0183180.

53. Sithole Z, Mbizvo E, Chonzi P, Mungati M, Juru TP, Shambira G, et al. Virological failure among adolescents on ART, Harare City, 2017- a case-control study. BMC Infect Dis. 2018;18. doi:10.1186/s12879-018-3372-6.

\section{Tables}

Table 1. Characteristic of adolescents included in the COHADO cohort compared to adolescent not included, Abidjan (Côte d’Ivoire), Lomé (Togo), leDEA-pWADA, 2015-2017

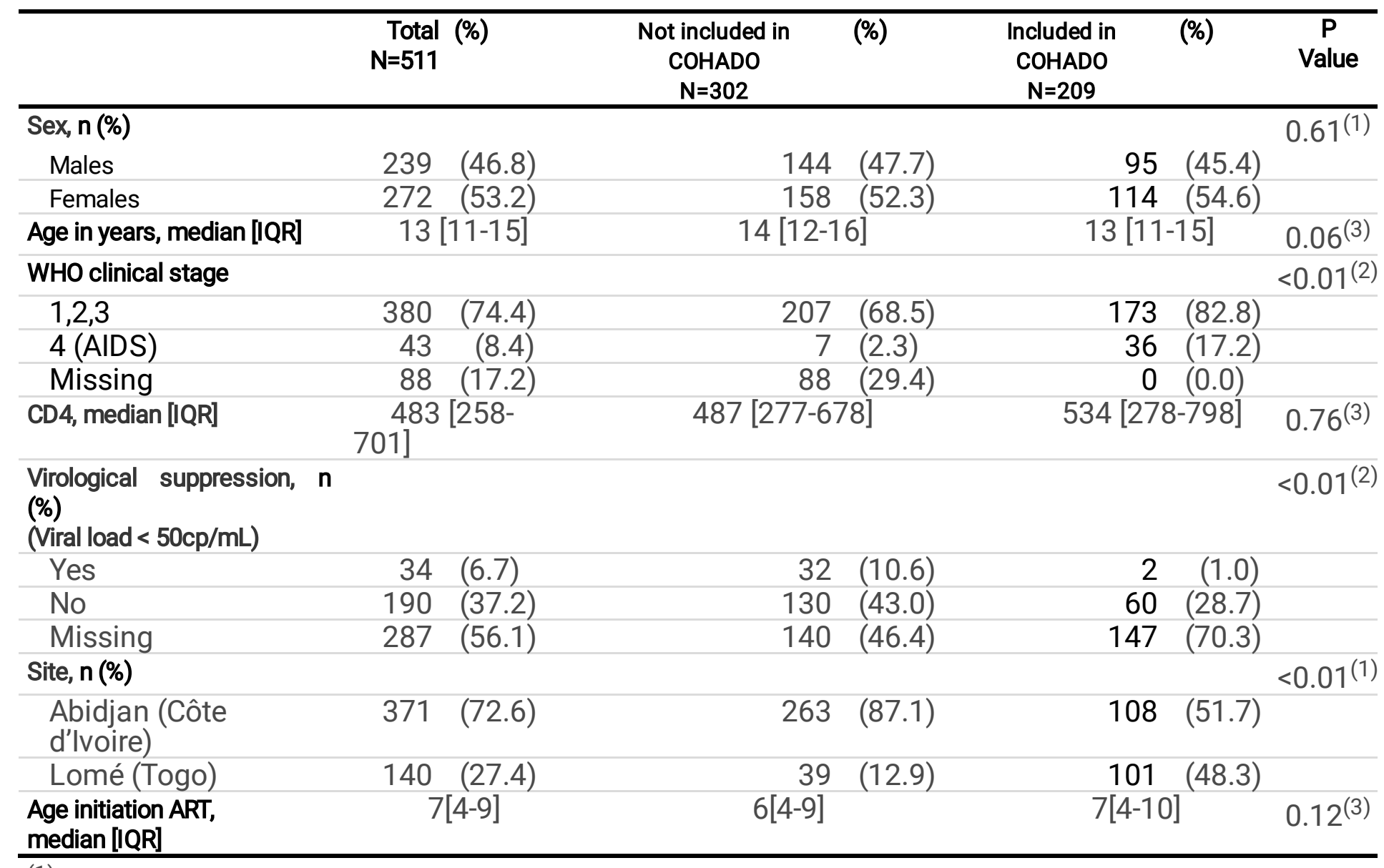

${ }^{(1)}$ Chi2 test $\quad{ }^{(2)}$ Fisher's exact test $\quad{ }^{(3)}$ Wilcoxon-Mann-Whitney test 
Table 2. Baseline characteristics of the 209 APHIV included in the COHADO cohort, Abidjan (Côte d'Ivoire), Lomé (Togo) leDEA-pWADA, 2015-2017 


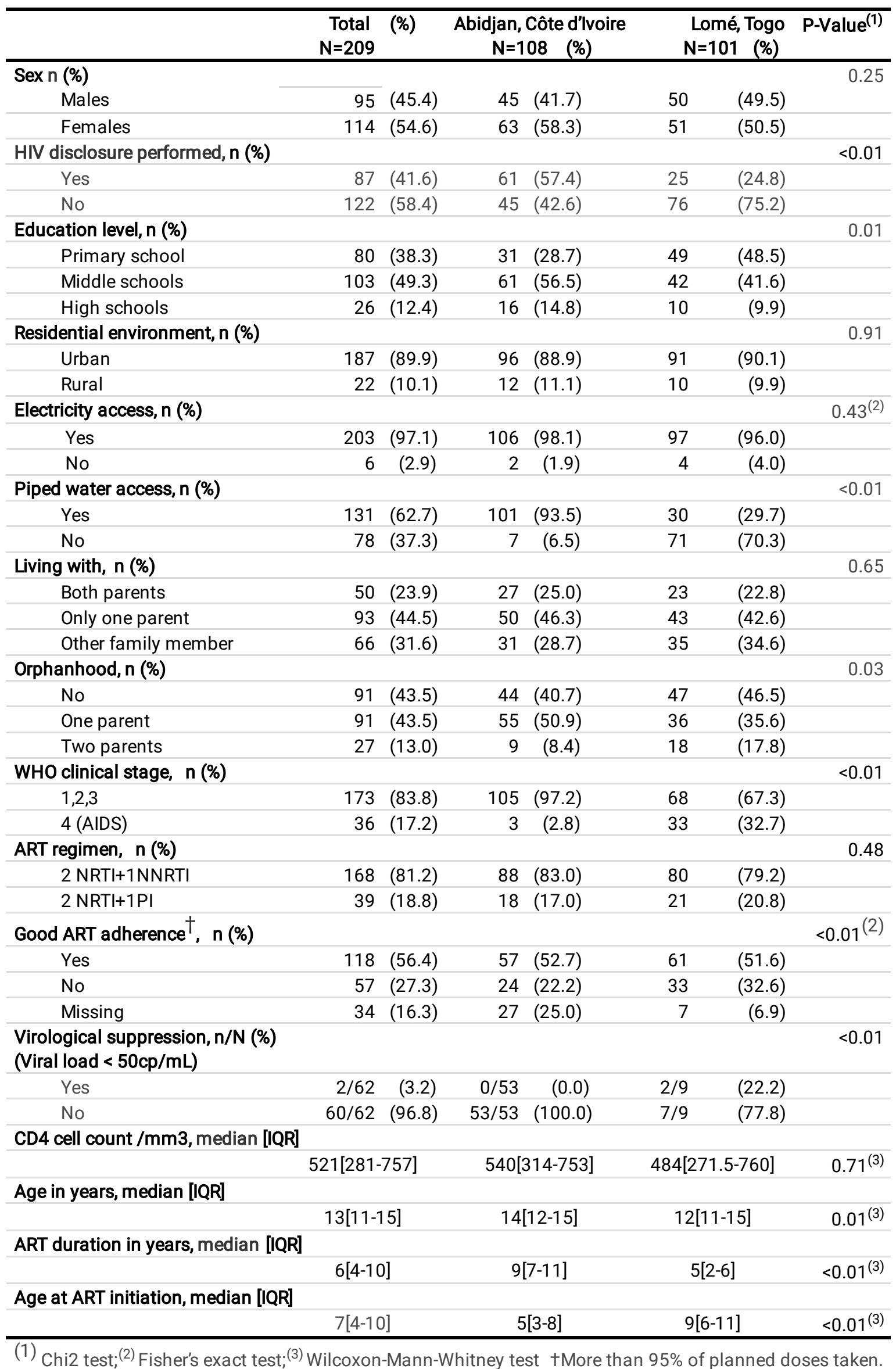


Table 3. 24-month outcomes of the 209 APHIV included, by site, in the COHADO cohort, leDEA-pWADA, 2015-2017

\begin{tabular}{|c|c|c|c|c|c|c|}
\hline & $\begin{array}{r}\text { Total } \\
\mathrm{N}=209\end{array}$ & (\%) & 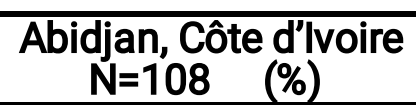 & & $\begin{array}{l}\text { né, Togo } \\
101 \quad \%)\end{array}$ & P Value ${ }^{(1)}$ \\
\hline HIV-disclosure performed, n (\%) & & & & & & $<0.01$ \\
\hline No & 54 & $(25.9)$ & $31 \quad(28.7)$ & 23 & $(22.8)$ & \\
\hline Yes (Since $\leq 2$ years) & 68 & $(32.5)$ & $15(13.9)$ & 53 & (52.5) & \\
\hline Yes (Since $>2$ years) & 87 & $(41.6)$ & $62(57.4)$ & 25 & (24.7) & \\
\hline Follow-up, n (\%) & & & & & & $0.18^{(2)}$ \\
\hline Died & 6 & (2.9) & $4 \quad(3.7)$ & 2 & (2.0) & \\
\hline Lost to follow-up & 8 & $(3.8)$ & $3 \quad(2.8)$ & 5 & $(4.9)$ & \\
\hline Transfered out & 4 & (1.9) & (3.7) & 0 & $(0.0)$ & \\
\hline Alive \& follow-up & 191 & (91.4) & $97 \quad(89.8)$ & 94 & (93.1) & \\
\hline $\begin{array}{l}\text { Progression to AIDS WHO } \\
\text { stage, } \mathbf{n}(\%)\end{array}$ & & & & & & $<0.01^{(2)}$ \\
\hline No & 154 & (73.7) & 91 (84.2) & 63 & $(62.4)$ & \\
\hline Yes & 7 & (3.4) & $5 \quad(4.6)$ & 2 & $(2.0)$ & \\
\hline Not applicable & 48 & $(22.9)$ & 11 (11.2) & 35 & (35.6) & \\
\hline $\begin{array}{l}\text { CD } 4 \text { count } \geq \text { baseline } \\
\text { value }( \pm 10 \%), n(\%)\end{array}$ & & & & & & $<0.01$ \\
\hline No & 76 & (36.3) & $55 \quad(51.4)$ & 21 & $(21.0)$ & \\
\hline Yes & 131 & $(62.7)$ & $52(48.6)$ & 79 & $(69.0)$ & \\
\hline Missing & 2 & $(1.0)$ & $1 \quad(1.0)$ & 1 & $(1.0)$ & \\
\hline $\begin{array}{l}\text { Viral load undetectable } \\
(<50 \mathrm{cp} / \mathrm{mL})\end{array}$ & & & & & & 0.01 \\
\hline No & 73 & (34.9) & $56 \quad(51.8)$ & 17 & $(16.8)$ & \\
\hline Yes & 102 & $(48.8)$ & $49(45.4)$ & 53 & (52.5) & \\
\hline Missing & 34 & (16.3) & $3 \quad(2.8)$ & 31 & $(30.7)$ & \\
\hline Combined criteria (above), n (\%) & & & & & & 0.01 \\
\hline Favorable & 94 & $(45.0)$ & $32 \quad(29.6)$ & 62 & (61.4) & \\
\hline Unfavorable & 115 & $(55.0)$ & $76(70.4)$ & 39 & $(38.6)$ & \\
\hline
\end{tabular}

Table 4. 24-month characteristics of the 209 APHIV included according to HIV-serostatus disclosure, in the COHADO cohort, Abidjan (Côte d'Ivoire), Lomé (Togo), leDEA-pWADA, 2015-2017 


\begin{tabular}{|c|c|c|c|c|}
\hline & $\begin{array}{c}\text { Total } \\
\mathrm{N}=209\end{array}$ & $\begin{array}{l}\text { HIV-serostatus } \\
\text { disclosed } \\
\mathrm{N}=155 \quad(\%)\end{array}$ & $\begin{array}{l}\text { HIV-serostatus } \\
\text { non disclosed } \\
\mathrm{N}=54 \\
\begin{array}{l}\text { (\%) } \\
\text { (\%) }\end{array}\end{array}$ & P-Value ${ }^{(1)}$ \\
\hline Sex, n (\%) & & & & 0.86 \\
\hline Males & $95(45.4)$ & $71(45.8)$ & $24(44.4)$ & \\
\hline Females & $114(54.6)$ & $84(54.2)$ & $30(55.6)$ & \\
\hline Site, n (\%) & & & & 0.34 \\
\hline Abidjan (Côte-d'Ivoire) & $108(51.7)$ & 77 (49.7) & $31(57.4)$ & \\
\hline Lomé (Togo) & 101 (48.3) & $78(50.3)$ & $23(42.6)$ & \\
\hline Orphanhood, n (\%) & & & & 0.32 \\
\hline No & $91(43.5)$ & $63(40.7)$ & $28(46.5)$ & \\
\hline One parent & $91(43.5)$ & $70(50.9)$ & $21(35.6)$ & \\
\hline Two parents & $27(13.0)$ & $22(8.4)$ & $5(17.8)$ & \\
\hline WHO clinical stage, $n$ (\%) & & & & $0.32^{(2)}$ \\
\hline $1,2,3$ & $164(78.5)$ & $118(76.1)$ & $46(85.2)$ & \\
\hline 4 (AIDS) & $43(20.6)$ & $35(22.6)$ & $8(14.8)$ & \\
\hline Missing & $2(0.9)$ & $2(1.3)$ & $0 \quad(0.0)$ & \\
\hline $\begin{array}{l}\text { Virological suppression }(n= \\
\text { (Viral load }<50 \mathrm{cp} / \mathrm{mL})\end{array}$ & & & & $<0.24$ \\
\hline Yes & $102(58.3)$ & $73(55.7)$ & $29(65.9)$ & \\
\hline No & $73(41.7)$ & $58(44.3)$ & $15(34.1)$ & \\
\hline \multicolumn{5}{|c|}{ CD4 cell count /mm3, median [IQR] } \\
\hline & $523[353-785]$ & $508[348-750]$ & $596[455-871]$ & $0.04^{(3)}$ \\
\hline \multirow[t]{2}{*}{ Age in years, median [IQR] } & \multirow[b]{2}{*}{ 15[13-17] } & & & \\
\hline & & $16[14-18]$ & $13[12-14]$ & $<0.01^{(3)}$ \\
\hline
\end{tabular}

${ }^{(1)}$ Chi2 test; ${ }^{(2)}$ Fisher's exact test; ${ }^{(3)}$ Wilcoxon-Mann-Whitney test

Table 5. Characteristics of HIV-disclosure process to the 155 APHIV disclosed by last contact, by site in the COHADO cohort, leDEA-pWADA, 2015-2017

\begin{tabular}{|c|c|c|c|c|c|c|}
\hline & $\begin{array}{l}\text { Total } \\
\mathrm{N}=155\end{array}$ & (\%) & $\begin{array}{c}\text { Abidjan, } \\
\text { Côte d'lvoire } \\
\text { N=77 }\end{array}$ & (\%) & $\begin{array}{c}\begin{array}{c}\text { Lomé, Togo } \\
N=78\end{array} \\
\text { c. }\end{array}$ & (\%) \\
\hline \multicolumn{7}{|l|}{ Person involved in disclosure, $\mathrm{n}(\%)$} \\
\hline Mother & 41 & (28.1) & 30 & $(43.5)$ & 11 & (14.3) \\
\hline Father & 22 & (15.6) & 18 & $(26.1)$ & 4 & $(5.2)$ \\
\hline Doctors & 8 & (5.5) & 6 & $(8.7)$ & 2 & (2.6) \\
\hline Psychologist & 84 & (56.7) & 25 & (36.2) & 59 & (76.6) \\
\hline Counsellor & 3 & $(2.1)$ & 0 & $(0.0)$ & 3 & $(2.1)$ \\
\hline Other (Family or association members) & 3 & (2.1) & 0 & $(0.0)$ & 3 & $(2.1)$ \\
\hline \multicolumn{7}{|l|}{ Disclosure performed before ART initiation } \\
\hline Yes & 13 & (8.4) & 6 & (7.8) & 7 & $(8.4)$ \\
\hline No & 133 & (85.8) & 64 & $(83.1)$ & 69 & $(88.5)$ \\
\hline Unknown & 9 & $(5.8)$ & 7 & (9.1) & 2 & $(2.6)$ \\
\hline
\end{tabular}


Table 6. Correlates of favourable combined 24-month outcome of the 209 APHIV included, in the COHADO, leDEA-pWADA, 2015-2017 


\begin{tabular}{|c|c|c|c|c|c|c|c|c|c|c|c|c|c|}
\hline & \multicolumn{7}{|c|}{ Univariate analysis } & \multicolumn{6}{|c|}{ Multivariate analysis } \\
\hline & \multirow{2}{*}{\multicolumn{2}{|c|}{$\begin{array}{l}\text { Unfavorable } \\
n=115 \text { (\%) }\end{array}$}} & \multirow{2}{*}{\multicolumn{2}{|c|}{$\begin{array}{l}\text { Favourable } \\
n=94(\%)\end{array}$}} & \multirow[b]{2}{*}{ OR } & \multirow[b]{2}{*}{$\begin{array}{l}(95 \% \\
\mathrm{Cl})\end{array}$} & \multirow[b]{2}{*}{$\begin{array}{l}\mathrm{p} \\
\text { value }\end{array}$} & \multicolumn{3}{|c|}{ Initial model } & \multicolumn{3}{|c|}{ Final model } \\
\hline & & & & & & & & $\mathrm{aOR}$ & $\begin{array}{l}(95 \% \\
\mathrm{Cl})\end{array}$ & $\begin{array}{l}\mathrm{P} \\
\text { value }\end{array}$ & aOR & $\begin{array}{l}(95 \% \\
\mathrm{Cl}) \\
\end{array}$ & $\begin{array}{l}\mathrm{p} \\
\text { value }\end{array}$ \\
\hline HIV-Disclosure & & & & & 0.79 & $\begin{array}{l}(0.56- \\
1.11)\end{array}$ & 0.17 & & & 0.45 & & & 0.35 \\
\hline No & 27 & $(23.5)$ & 27 & $(28.7)$ & 1.00 & --- & --- & 1.00 & & & 1.00 & - & - \\
\hline $\begin{array}{l}\text { Yes (Since } \leq 2 \\
\text { years) }\end{array}$ & 35 & $(30.4)$ & 33 & $(35.1)$ & 0.94 & $\begin{array}{l}(0.46- \\
1.92)\end{array}$ & 0.87 & 0.48 & $\begin{array}{l}(0.20- \\
1.16)\end{array}$ & 0.10 & 0.50 & $\begin{array}{l}(0.21- \\
1.15)\end{array}$ & 0.10 \\
\hline $\begin{array}{l}\text { Yes (Since > } 2 \\
\text { years) }\end{array}$ & 53 & $(46.1)$ & 34 & $(36.2)$ & 0.64 & $\begin{array}{l}(0.32- \\
1.27)\end{array}$ & 0.20 & 0.67 & $\begin{array}{l}(0.24- \\
1.82)\end{array}$ & 0.43 & 0.65 & $\begin{array}{l}(0.25- \\
1.72)\end{array}$ & 0.39 \\
\hline \multicolumn{14}{|l|}{ Site } \\
\hline $\begin{array}{l}\text { Abidjan, Côte- } \\
\text { d'Ivoire }\end{array}$ & 76 & $(66.1)$ & 32 & (34.1) & 1.00 & --- & --- & 1.00 & & & 1.00 & - & - \\
\hline Lomé, Togo & 39 & $(33.9)$ & 62 & $(65.9)$ & 3.77 & $\begin{array}{l}(2.12- \\
6.71)\end{array}$ & $<0.01$ & 5.11 & $\begin{array}{l}(1.93- \\
13.5)\end{array}$ & 0.01 & 4.41 & $\begin{array}{l}(2.29- \\
8.50)\end{array}$ & $<0.01$ \\
\hline \multicolumn{14}{|l|}{ Sex } \\
\hline Males & 48 & $(41.7)$ & 47 & $(50.0)$ & 1.00 & --- & --- & 1.00 & & & 1.00 & - & - \\
\hline Females & 67 & $(58.3)$ & 47 & $(50.0)$ & 0.71 & $\begin{array}{l}(0.41- \\
1.23)\end{array}$ & 0.23 & 0.79 & $\begin{array}{l}(0.43- \\
1.46)\end{array}$ & 0.46 & 0.76 & $\begin{array}{l}(0.42- \\
1.36)\end{array}$ & 0.35 \\
\hline Education level & & & & & 0.89 & $\begin{array}{l}(0.58- \\
1.33)\end{array}$ & 0.57 & & & & & & \\
\hline Primary school & 41 & $(35.6)$ & 39 & $(41.5)$ & 1.00 & --- & --- & & & & & & \\
\hline Middle schools & 60 & $(52.2)$ & 43 & $(45.7)$ & 0.75 & $\begin{array}{l}(0.41- \\
1 ; 35)\end{array}$ & 0.34 & & & & & & \\
\hline High schools & 14 & $(12.2)$ & 12 & $(12.8)$ & 0.90 & $\begin{array}{l}(0.37- \\
2.18)\end{array}$ & 0.81 & & & & & & \\
\hline \multicolumn{14}{|l|}{ Piped water access } \\
\hline Yes & 81 & $(70.4)$ & 50 & $(53.2)$ & 1.00 & --- & --- & 1.00 & & & & & \\
\hline No & 34 & $(29.6)$ & 44 & $(46.8)$ & 2.09 & $\begin{array}{l}(1.18- \\
3.70)\end{array}$ & 0.01 & 0.82 & $\begin{array}{l}(0.43- \\
1.98)\end{array}$ & 0.67 & & & \\
\hline \multicolumn{14}{|l|}{$\begin{array}{l}\text { Electricity access, } n \\
(\%)\end{array}$} \\
\hline No & 3 & (2.6) & 3 & (3.2) & 1.00 & --- & --- & & & & & & \\
\hline Yes & 112 & $(97.4)$ & 91 & $(96.8)$ & 1.23 & $\begin{array}{l}(0.24- \\
6.24)\end{array}$ & 0.80 & & & & & & \\
\hline \multicolumn{14}{|l|}{$\begin{array}{l}\text { Residential } \\
\text { environment }\end{array}$} \\
\hline Urban & 100 & (86.9) & 87 & (92.6) & 1.00 & --- & --- & 1.00 & & & & & \\
\hline Rural & 15 & $(13.1)$ & 7 & (7.4) & 0.53 & $\begin{array}{l}(0.21- \\
1.37)\end{array}$ & 0.19 & 0.52 & $\begin{array}{l}(0.18- \\
1.44)\end{array}$ & 0.21 & & & \\
\hline living with & & & & & 0.77 & $\begin{array}{l}(0.53- \\
1.12)\end{array}$ & 0.17 & & & & & & \\
\hline Both parents & 25 & $(21.7)$ & 25 & $(26.6)$ & 1.00 & --- & --- & 1.00 & & & & & \\
\hline Only one parent & 49 & $(42.6)$ & 44 & $(46.8)$ & 0.89 & $\begin{array}{l}(0.45- \\
1.78)\end{array}$ & 0.75 & 1.24 & $\begin{array}{l}(0.50- \\
3.11)\end{array}$ & 0.63 & & & \\
\hline $\begin{array}{l}\text { Other family } \\
\text { member }\end{array}$ & 41 & $(35.7)$ & 25 & $(26.6)$ & 0.60 & $\begin{array}{l}(0.28- \\
1.28)\end{array}$ & 0.19 & 0.77 & $\begin{array}{l}(0.24- \\
2.45)\end{array}$ & 0.66 & & & \\
\hline Orphanhood & & & & & 0.70 & $\begin{array}{l}(0.47- \\
1.06)\end{array}$ & 0.09 & & & & & & \\
\hline No & 42 & $(36.5)$ & 49 & (52.1) & 1.00 & --- & --- & 1.00 & & & & & \\
\hline One parent & 58 & $(50.4)$ & 33 & (35.1) & 0.48 & $\begin{array}{l}(0.26- \\
0.88)\end{array}$ & 0.01 & 0.57 & $\begin{array}{l}(0.24- \\
1.35)\end{array}$ & 0.20 & & & \\
\hline Two parents & 15 & $(13.1)$ & 12 & (12.8) & 0.68 & $\begin{array}{l}(0.28- \\
1.62)\end{array}$ & 0.39 & 0.69 & $\begin{array}{l}(0.19- \\
2.44)\end{array}$ & 0.57 & & & \\
\hline
\end{tabular}




\begin{tabular}{|c|c|c|c|c|c|c|c|c|c|c|c|c|}
\hline $1,2,3$ & & $101 \quad$ (87.8) & 72 (76.6) & 1.00 & ---- & --- & 1.00 & & & & & \\
\hline 4 & & $14 \quad(12.2)$ & $22 \quad(23.4)$ & 2.20 & $\begin{array}{l}(1.05- \\
4.59)\end{array}$ & 0.03 & 1.02 & $\begin{array}{l}(0.42- \\
2.49)\end{array}$ & 0.95 & & & \\
\hline $\begin{array}{l}\text { Baseline age } \\
\text { years }\end{array}$ & & 13 [11-15] & 13[11-15] & 0.96 & $\begin{array}{l}(0.86- \\
1.07)\end{array}$ & 0.54 & 1.03 & $\begin{array}{l}(0.87- \\
1.22)\end{array}$ & 0.66 & 1.03 & $\begin{array}{l}(0.88- \\
1.20)\end{array}$ & 0.64 \\
\hline $\begin{array}{l}\text { Baseline CD4 } \\
\text { cells } / \mathrm{mm}^{3}\end{array}$ & & $\begin{array}{c}540[265- \\
806]\end{array}$ & $\begin{array}{c}\text { 484[299- } \\
751]\end{array}$ & 0.99 & $\begin{array}{l}(0.99- \\
1.00)\end{array}$ & 0.41 & 0.99 & $\begin{array}{l}(0.99- \\
1.00)\end{array}$ & 0.37 & & & \\
\hline
\end{tabular}

Figures

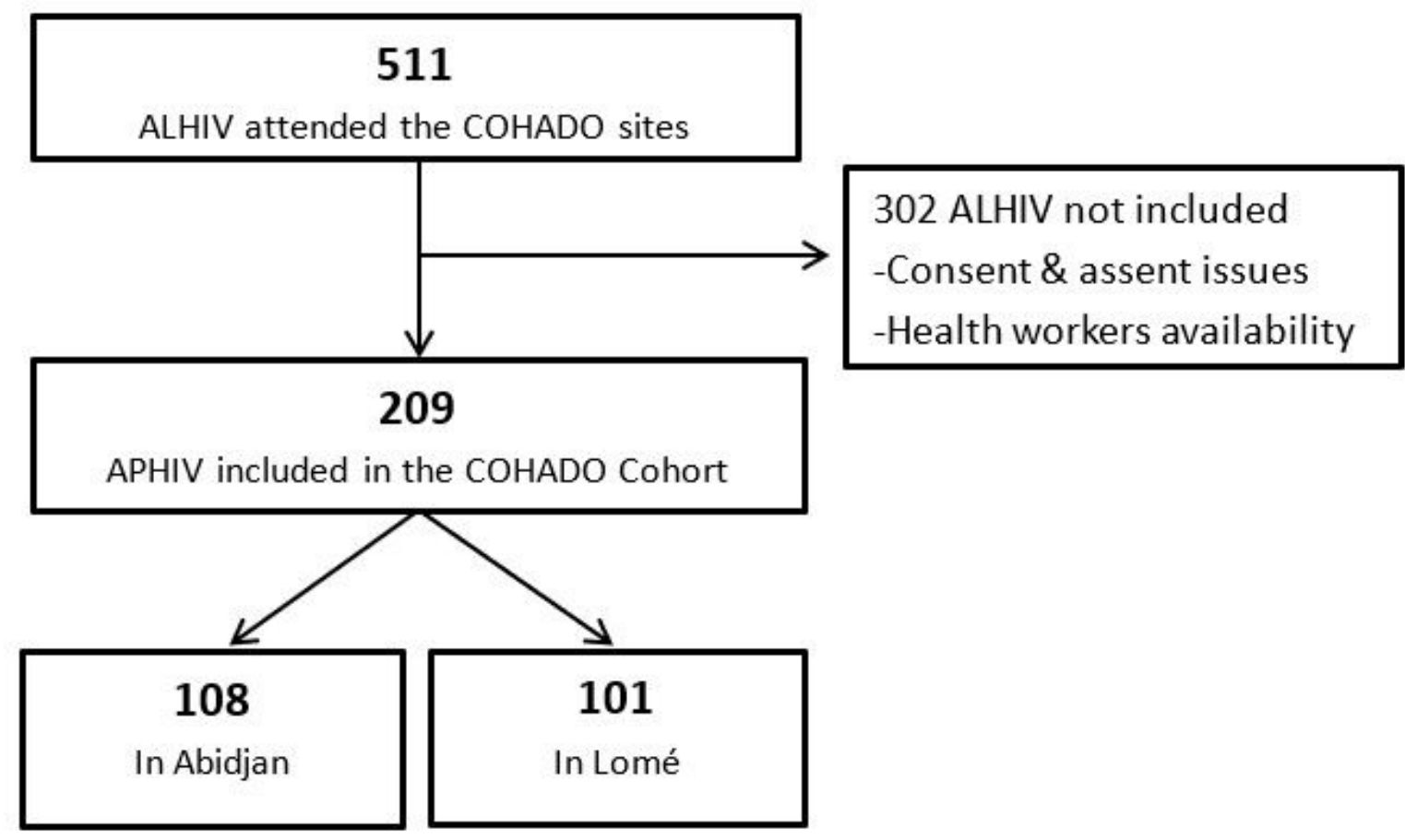

Figure 1

Flow chart of inclusion of 209 APHIV in the COHADO Cohort, leDEA-pWADA, 2015. 